\title{
Knowledge of women with visual impairment about the human papillomavirus and risk factors
}

\author{
Conhecimento de mulheres com deficiência visual sobre o Papilomavírus Humano e fatores \\ de risco
}

Inacia Sátiro Xavier de França ${ }^{1}$, Caroline Gomes Maciel $^{1}$, Jamilly da Silva Aragão ${ }^{1}$, Alexsandro Silva Coura ${ }^{1}$, Aldenice Oliveira dos Santos ${ }^{1}$, Arthur Felipe Rodrigues Silva ${ }^{1}$

Objective: to identify the knowledge of women visual impairment about the human papillomavirus and its association with risk factors. Methods: cross-sectional study with 29 women with visual impairment using a questionnaire containing demographic variables, risk factors and knowledge about the human papillomavirus. The analysis was performed using analytical and descriptive statistics, Fisher's test, considering the significance level of $5 \%$. Results: most participants said that they had already heard about the human papillomavirus (86.2\%). One verified an association between the knowledge about the virus and the age of first sexual intercourse, the preventive Papanicolaou test and the frequency and use of condom. Conclusion: women with visual impairment, although with limitations, show knowledge about the human papillomavirus. This knowledge was associated with risk factors.

Descriptors: Visually Impaired Persons; Women's Health; Papillomaviridae.

Objetivo: identificar o conhecimento das mulheres com deficiência visual sobre o Papilomavírus Humano e sua associação com fatores de risco. Métodos: estudo transversal, com 29 mulheres com deficiência visual, utilizando questionário contendo variáveis: sociodemográficas, fatores de risco, conhecimento sobre Papilomavírus Humano. Na análise utilizou-se estatística descritiva e analítica, teste de Fisher, considerando o nível de significância de 5\%. Resultados: a maioria das participantes afirmou já ter ouvido falar sobre o Papilomavírus Humano (86,2\%). Verificou-se associação entre o aspecto conhecimento sobre este vírus com a idade da primeira relação sexual, o exame preventivo de Papanicolau e a frequência e o uso do preservativo. Conclusão: as mulheres com deficiência visual, embora com limitações, apresentam conhecimento sobre o Papilomavírus Humano. Esse conhecimento esteve associado aos fatores de risco.

Descritores: Pessoas com Deficiência Visual; Saúde da Mulher; Papillomaviridae.

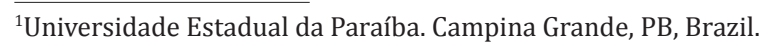

Corresponding author: Inacia Sátiro Xavier de França

Rua Sérgio Rodrigues de Oliveira, 139. Alto Branco. CEP: 58401-566. Campina Grande, PB, Brazil. E-mail: inacia.satiro@gmail.com 


\section{Introduction}

The human papillomavirus is considered the most common agent of sexually transmitted infections and it has a big social impact worldwide. This grievance is prevalent in young adults, and it is more severe when diagnosed in women because of their direct relationship with cancer of the cervix ${ }^{(1)}$.

Among the 189 types of viruses identified, it is reported that the human papillomavirus (HPV) has a numbered classification in the following order: virus of low oncogenic risk $(6,11,30,42,43$ and 44$)$ and those of high risk $(16,18,31,33,35,39,45,51,52$, $56,58,59$ and 68$)$. It should be noted that the oncogenic potential of this virus has a relation with the viral type, persistence and integration of the viral deoxyribonucleic acid and the host cell(2).

In regions such as Bangladesh, in Asia, women had higher risk of infection with human papillomavirus of types HPV16, HPV18, HPV31, HPV45, HPV53 and HPV66 with $7.7 \%$ of cases in 1,902 women with ages from 18 to 59 years old examined in a cohort study. In the US, the incidence rate of infection by oral HPV in students from 18 to 30 years old was 5.67 per 1,000 people/month, demonstrated in a study by the Ohio State University, and the factor kiss in the mouth and oral sex over life was associated with the infection $^{(3-4)}$.

In the case of cervical cancer, Latin America has one of the highest incidence rates in the world ${ }^{(5)}$. In Brazil, it is the third most common tumor in the female population ${ }^{(6)}$. The infection with the HPV virus is a high-risk one, from the Alphapapillomavirus type, and this factor leads to an unusual growth of cells located in the lower part of the uterus as well as the action of oncogenic proteins that cause cervical lesions ${ }^{(7)}$.

Although the human papillomavirus is the main risk factor for the development of cervical cancer, this cancer is associated with persistent infections with oncogenic subtypes of this virus and the possibility of regression or persistence of the infection depends on reproductive characteristics, sexual behavior, precoci- ty of sexual activity, multiple sexual partners, prolonged use of oral contraceptives, in addition to living habits, smoking, inadequate personal hygiene, and lack of knowledge about the causes of the disease $\mathrm{e}^{(8-9)}$.

Given the epidemiological data, monitoring of cancer morbidity and mortality is a routine in Brazil, run by a monitoring system whose information subsidize the analysis for decision-making about the prevention and control of cancer and its risk factors. Among the national programs for the prevention and control of cancer, the information centralized by the Secretary of Health Surveillance stands out. The information obtained is disseminated through regulatory and technical documents aimed to guide strategic decision making in all levels $\mathbf{s}^{(4)}$.

In 2014 the need to prevent infections by the human papillomavirus led the Ministry of Health to include in its immunization schedule the tetravalent vaccine subtypes $6,11,16$ and 18 of this virus to girls from 9 to 13 years of age. It is explained that the subtypes 11 and 16 cause genital warts and 16 and 18 are responsible for nearly $70.0 \%$ of cases of cervical cancer. Furthermore, when the women who were vaccinated reach the recommended age, they need to perform the screening test because the vaccine does not protect against all oncogenic subtypes of the human papillomavirus ${ }^{(4)}$.

In this context, women with disabilities deserve attention because they constitute part of the population with vulnerability to health risks ${ }^{(10)}$ About disabilities in Brazil, the 2010 census showed that 23.0\% of the population have at least one disability - visual, auditory, motor, mental or intellectual. Considering 45,606,048 million Brazilians, visual impairment accounted for the highest number of cases in relation to other types of disability, affecting $18.6 \%$ of the population. Regarding gender, women had a higher prevalence of visual and motor impairment, and had men a slightly higher prevalence of hearing and mental disabilities $^{(11)}$.

With the identification of the knowledge of women with visual impairment about the human papillo- 
mavirus, it is possible to understand the conception of this disease and its relationship with cervical cancer in this social segment, in addition to support the actions undertaken by health professionals, especially nurses who are great disseminators of information and in their practice they have as an intervention instrument the health education, and thus, they are able to ensure greater health promotion activities for people with visual impairment and contribute to the fight against major factors risk.

Thus, due to the difficulties of access to information about sexual and reproductive health experienced by women with visual impairment, the increase in infections by human papillomavirus, and the vulnerability of people with disabilities to health diseases, one selected the question: What information about human papillomavirus and cervical cancer do women with visual impairment have? To answer this question, one aimed to identify the knowledge of women with visual impairment about the human papillomavirus and its association with risk factors.

\section{Methods}

This is a cross-sectional study conducted at an institute for blind people in Campina Grande, PB, Brazil, from August 2014 to June 2015.

Thirty-four women with visual impairment were invited for the study. Among these women, we excluded: a woman, for presenting visual and mental disability concurrently, three women who refused to participate, and four who did not attend the institute regularly. Thus, the sample consisted of 29 women who met the inclusion criteria: aged from 18 to 59 years old; with visual impairment, congenital or acquired (visual acuity ranging from blindness to low vision), sexually active or not, and who attended the activities of the institute.

Data collection occurred after a previous visit to the institution for clarifications about the research and schedule of days and times for the interviews with the participants. Interviews were held individually in a place reserved at the institute, with an average duration of 15 minutes. The instrument was a structured questionnaire based on the guide from the National Institute of Science and Technology of Papillomavirus Related Diseases ${ }^{(5)}$, containing 30 questions including sociodemographic variables, knowledge variables about HPV: clinical manifestations, complications, way of transmission and risk factors, as well as variables related to the individuals' sexual practices that interfere with sexual health. The answers to the questions were written in the questionnaire by the researcher. At the end of the interview, the answers were read for confirmation of the interviewees.

The data were analyzed by using descriptive and analytical statistics through the software Statistical Package for Social Sciences, Windows version 20.0 and presented in tables. Fisher's exact test was performed, considering a level of significance of $5 \%$.

The study respected with the formal requirements contained in the national regulatory and international standards for research involving human beings.

\section{Results}

Among the participants, 15 were 35 years old and 14 were aged between 18 and 34 years old. In the study 16 women reported not having a partner, and 13 said that they had a partner. About religion, 29 participants said that they had religious beliefs. The level of education was 10 years of study for 10 participants and less than 10 years for the other 19. About income, 25 participants reported receiving a minimum wage, one of them reported receiving less than one minimum wage, and three denied receiving any value at all.

It was found out that $89.7 \%$ of the participants had their first sexual relationship after 16 years of age, $62.1 \%$ do not use condoms, $82.8 \%$ have access to health services, $55.2 \%$ do preventive examinations at least annually, and $79.3 \%$ reported no history of sexually transmitted infections.

Regarding the knowledge of the participants 
about the human papillomavirus, risk factors and clinical manifestations of infection with this virus, the measurement of their responses are presented in Table 1.

Table 1 - Distribution referring to the knowledge of visually impaired women about the human papillomavirus

\begin{tabular}{lcc}
\hline \multirow{2}{*}{ Knowledge about the human papillomavirus } & Yes & No \\
\cline { 2 - 2 } & $\mathrm{n}(\%) \quad \mathrm{n}(\%)$ \\
\hline
\end{tabular}
Women who have already heard about the human $25(86.2) \quad 4(14.8)$
papillomavirus

Belief that the human papillomavirus, regarding sex, affects:

$\begin{array}{lcc}\text { Men } & 1(3.4) & - \\ \text { women } & 4(13.8) & - \\ \text { Men and women } & 24(82.8) \quad-\end{array}$

Ways of transmition of the human papillomavirus

Contact with infected skin or mucosa

14 (48.3) 15 (51.7)

Sexually (oral-genital-anal)

Vertical transmission

Contact with unhealthy skin

Contact with individual objects

Risk factors for human papillomavirus

Risky sexual behavior*

Impaired immune state

Genetic predisposition

Poor nutritional status

Smoking

Injured genital mucosa

History of sexually transmitted infection

Clinical manifestations

Warts with cauliflower aspect

Pain during sexual intercourse

Intraepithelial lesion

Bullous lesion

Purulent discharge

Complications

Cervical cancer

$28(96.6) \quad 1(3.4)$

Genital warts

Precancerous lesions

${ }^{*}$ Sex without the use of condom, multiple partners and early sexual initiation

18 (62.1) 11 (37.9)

11 (37.9) 18 (62.1)

7 (24.1) 22 (75.9)

9 ( (31.0) 20 (69.0)

$20(69.0) 9(31.0)$

18 (62.1) 11 (37.9)

17 (58.6) 12 (41.4)

19 (65.5) $10(34.5)$

16 (55.2) 13 (44.8)

$10(34.5) 19(65.5)$

17 (58.6) 12 (41.4)
The association between the knowledge of women who reported "having heard about HPV" with the risk factors for this virus is shown in Table 2.

Table 2 - Association between the knowledge of women with visual impairment about the human papillomavirus and the risk factors for this virus

\begin{tabular}{|c|c|c|c|}
\hline \multirow{2}{*}{$\begin{array}{l}\text { Risk factors for the human papilloma- } \\
\text { virus }\end{array}$} & \multicolumn{3}{|c|}{$\begin{array}{l}\text { Has already heard about } \\
\text { the human papillomavirus }\end{array}$} \\
\hline & $\begin{array}{c}\text { Yes } \\
\text { n(\%) }\end{array}$ & $\begin{array}{c}\text { No } \\
\text { n(\%) }\end{array}$ & $\mathbf{p}$ \\
\hline
\end{tabular}

Age of first sexual intercourse (years)

\begin{tabular}{|c|c|c|}
\hline$\leq 16$ & $1(33.3)$ & $2(66.7)$ \\
\hline
\end{tabular}

$>16$

24(92.3) 2(7.7)

Use of condom

Yes

$11(100.0)$

No

$14(77.8) \quad 4(22.2)$

Number of partners $(\mathrm{n}=21)$

Only one partner

11(91.7) 1(8.3)

$>1$ partner

$9(100.0)$

Access to health services

Yes

$22(91.7) \quad 2(8.3) \quad 0.126^{*}$

No

$3(60.0) \quad 2(40.0)$

Papanicolaou Test

Yes

$24(96.0) \quad 1(4.0) \quad 0.004^{*}$

No

$1(25.0) \quad 3(75.0)$

Frequency of the Papanicolaou Test

Consultation six months/one year

$16(100.0)$

Consultation > one year

$9(69.2) \quad 4(30.8)$

History of sexually transmitted infections

Yes

5(83.3) 1(16.7) $0.627 *$

No

$20(87.0) \quad 3(13.0)$

*Fisher 's Test

Table 3 shows the association between the "knowledge about the transmission of the human papillomavirus by direct contact with infected skin or mucosa" and the risk factors for this virus. 
Table 3 - Association between the knowledge of blind women about the transmission of the human papillomavirus by direct contact with infected skin or mucosa and the risk factors for this infection

\begin{tabular}{|c|c|c|c|}
\hline \multirow{2}{*}{$\begin{array}{l}\text { Risk factors for the human papilloma- } \\
\text { virus }\end{array}$} & \multicolumn{3}{|c|}{$\begin{array}{l}\text { Knowledge about the } \\
\text { transmission by contact } \\
\text { with infected skin/mucosa }\end{array}$} \\
\hline & $\begin{array}{c}\text { Yes } \\
\text { n(\%) }\end{array}$ & $\begin{array}{c}\text { No } \\
n(\%)\end{array}$ & $\mathbf{p}$ \\
\hline \multicolumn{4}{|l|}{ Age of first sexual intercourse (years) } \\
\hline$\leq 16$ & $3(100.0)$ & - & - \\
\hline$>16$ & $11(42.3)$ & $15(57.7)$ & \\
\hline \multicolumn{4}{|l|}{ Use of condom } \\
\hline Yes & $8(72.7)$ & $3(27.3)$ & $0.046^{*}$ \\
\hline No & $6(33.3)$ & $12(66.7)$ & \\
\hline \multicolumn{4}{|l|}{ Number of partners $(n=21)$} \\
\hline Only one partner & $6(50)$ & $6(50.0)$ & $0.575^{*}$ \\
\hline$>1$ partner & $4(44.4)$ & $5(55.6)$ & \\
\hline \multicolumn{4}{|l|}{ Access to health services } \\
\hline Yes & $10(41.7)$ & $14(58.3)$ & $0.143^{*}$ \\
\hline No & $4(80.0)$ & $1(20.0)$ & \\
\hline \multicolumn{4}{|l|}{ Papanicolaou Test } \\
\hline Yes & $12(48.0)$ & $13(52.0)$ & $0.674^{*}$ \\
\hline No & $2(50.0)$ & $2(50.0)$ & \\
\hline \multicolumn{4}{|l|}{ Frequency of the Papanicolaou Test } \\
\hline Consultation six months/one year & $5(31.2)$ & $11(68.8)$ & $0.048^{*}$ \\
\hline Consultation >one year & $9(69.2)$ & $4(30.8)$ & \\
\hline \multicolumn{4}{|l|}{ History of sexually transmitted infections } \\
\hline Yes & $3(50.0)$ & $3(50.0)$ & $0.639^{*}$ \\
\hline No & $11(47.8)$ & $12(52.2)$ & \\
\hline
\end{tabular}

\section{Discussion}

The results of this study have limitations such as generalizations due to the sample size and the reduced number of current investigations addressing the theme disabled people, sexually transmitted infections (STI) and Human Immunodeficiency Virus/ Acquired immunodeficiency syndrome (HIV/AIDS), making it difficult to perform approaches or to get distant from results reported by other researchers. However, this study offers tools for the practice of health education, both for the segment of people with disabilities, as for sex education at schools, a place with large numbers of teenagers, who are targets of vaccination campaigns against HPV. Furthermore, it is suggested the development of longitudinal studies for a better understanding of the cause and development of the disease and its treatment.

Regarding women's knowledge about the human papillomavirus, a study conducted in the state of Piauí, in Brazil, with 126 participants without disabilities, found out that $70.0 \%$ of the sample had already heard about the virus ${ }^{(3)}$ a result that suggests that the female population understands what the human papillomavirus is, knowing the course of the disease or not, which corroborates the results of the current study in which most participants already knew about the virus, its clinical manifestations and the complications arising from sexually transmitted infections.

About the risk factors for the human papillomavirus, the participants showed attitudes that favor the prevention against this infection, contributing for the prevention of cervical cancer, as there was a significant frequency of preventive factors of cervical cancer, such as: a single partner, access to health services, Papanicolaou test every six months or annually, and negative history of sexually transmitted infections.

However, more than half of the participants said that they did not use condoms during sexual intercourse, a result that resembles that of another study ${ }^{(12)}$ that focused on condom use by people with visual impairment and that found out that women yielded to their partners' will of not using condoms. In terms of sexuality, authors understand that submission of women's will to men's stems from the construction of gender roles, elaborated culturally, giving to man the full enjoyment of their sexuality and the dominant attitude in sex, leaving for women the repression of their wants and desires, the denial of belonging to their own bodies, placing them in the position of sexual objects for men ${ }^{(13)}$.

Considered the importance of condom use in the prevention of sexually transmitted diseases, there is also the need for education actions with specificity for people with disabilities, aiming to explain for couples about the risks of unprotected sex. 
Concerning the association of the knowledge about the human papillomavirus and its risk factors, one identified an association with the age of first sexual intercourse, since most of the participants reported the onset of their sexual life after 16 years of age. It is considered that sexual initiation before the age of 16 is premature because the cervix is not fully formed and hormone levels are not stabilized yet, increasing the risk for cervical complications. Likewise, the human papillomavirus acts silently, and when it is associated with early sexual intercourse, it may predispose women even more to its virulent action ${ }^{(14)}$.

There was an association between the knowledge about the human papillomavirus and the Papanicolaou test, showing that most of the participants know about the virus, and that they also perform this test frequently, indicating another positive factor in the prevention of this virus and of cervical cancer. There was also an association of the participants' knowledge about the transmission of the human papillomavirus by direct contact with infected skin or mucosa and the risk factors for this virus, as well as the association with condom use. But most participants who are unaware of the transmission of the human papillomavirus by contact with skin or mucosa do not use condom, and they may be vulnerable to the virus. In this sense, a research report indicates a probable vulnerability of blind people in relation to sexually transmitted infections because they show an improper sexual behavior ${ }^{(12)}$.

The non use of condoms by some participants may be due to socio-demographic factors ${ }^{(12)}$ their lack of knowledge, their perception of risk due to sexually transmitted infections, and due to the difficulty of women to negotiate condom use and safe sex practices, as in the contemporary society male attitudes connected to patriarchy and/or sexism still persist. Thus, a study with women who are able to see attended at a family health unit showed that most women do not use condoms in their sexual intercourses, as there is rejection of their partners. In turn, these women jus- tify the non use of condoms claiming discomfort, contraceptive use, and trust in their partners ${ }^{(15)}$.

Thus, it is necessary a greater prevention intervention for people with visual impairment, with trained professionals to facilitate communication and socialization of professionals and users, encouraging dialogue in relation to good sexual and reproductive health practices, promotion of condom use for the prevention of infection with the human papillomavirus and thus preventing the risk of cervical cancer, as well as their inclusion in the several programs, such as the one for prevention of STIs/HIV/ $\operatorname{AIDS}^{(10,16)}$.

\section{Conclusion}

It is concluded that most women with visual impairments, although with limitations, have knowledge about the human papillomavirus. This knowledge was associated with the risk factors: age of first sexual intercourse, preventive Papanicolaou test, the test frequency and condom use.

\section{Collaborations}

França ISX and Coura AS contributed to the conception, design, analysis, data interpretation and writing of the article. Maciel CG, Aragão JS, Santos AO and Silva AFR contributed to the analysis, interpretation of data and writing of the article. All the authors contributed to the relevant critical review of the content and approval of the final version to be published.

\section{References}

1. Chagas LLP, Neves JB. Rastreamento do papilomavírus humano (HPV) em mulheres com mais de 25 anos. Rev Enferm Integrada. 2013; 6(1):104351.

2. Santos JC, Cezar MRS, Lisboa MR, Moura MMF. Ocorrência de papilomavírus humano na cérvice uterina de mulheres da região ocidental da Amazônia Brasileira. Acta Amaz. 2013; 43(2):18590. 
3. Nahar Q, Sultana F, Alam A, Islam JY, Rahman M, Khatun F, et al. Infecção por papilomavírus humano genital entre mulheres em Bangladesh: resultados de uma pesquisa baseada na população. Plos One[Internet]. 2014 [citado 2017 mai 04[; 9(11):e114655. Disponível em: ttps://www.ncbi. nlm.nih.gov/pmc/articles/PMC4182674/

4. Pickard RK, Xiao W, Broutian TR, He X, Gillison ML. The prevalence and incidence of oral human papillomavirus infection among young men and women, aged 18 -30 years. Sex Transm Dis. 2012; 39(7):559-66.

5. Villa LL. Cervical cancer in Latin America and the Caribbean: the problem and the way to solutions. Cancer Epidemiol Biomarkers Prev. 2012; 21(9):1409-13.

6. França MCA, França MCS, Moraes SDS. Conhecimento de mulheres acerca do papilomavírus humano e sua relação com o câncer de colo uterino. Cogitare Enferm. 2013; 18(3):509-14.

7. Doorbar J, Quint J, Banks L, Bravo IG, Stoler M, Broker TR. Stanley MA. The biology and lifecycle of human papillomaviruses. Vaccine. 2012; 30(Suppl 5):55-70.

8. Rafael RMR, Moura ATMS. Exposição aos fatores de risco do câncer do colo do útero na Estratégia de Saúde da Família de Nova Iguaçu, Rio de Janeiro, Brasil. Cad Saúde Coletiva. 2012; 20(4):499-505.

9. Leite MF, Vitta FCF, Carnaz L, Conti MHS, Marta SN, Gatti MAN, et al.Knowledge and practice of women regarding cervical cancer in a primary health care unit. J Hum Growth Development. 2014; 24(2):208-13.

10. França DNO. Direitos sexuais, políticas públicas e educação sexual no discurso de pessoas com cegueira. Rev Bioética. 2014; 22(1):126-33.
11. Ministério da Saúde (BR). Secretaria Nacional de Promoção dos Direitos da Pessoa com Deficiência. Cartilha do Censo 2010. Coordenação Geral do Sistema de Informações sobre a Pessoa com Deficiência. Brasília: Ministério da Saúde; 2012.

12. Araújo AKF, França ISX, Coura AS, Santos SR, Ramos APA, Pagliuca LM. Sociodemographic profile of blind people: associations with knowledge, attitude and practice about sexually transmitted infections. Rev Rene. 2015; 16(5):738-45.

13. Arraes CO, Palos MAP, Barbosa MA, Teles SA, Souza MM, Matos MA. Masculinity, vulnerability and prevention of STD/HIV/AIDS among male adolescents: social representations in a land reform settlement. Rev Latino-Am Enfermagem. 2013; 21(6):1266-73.

14. Oliveira GR, Vieira VC, Barral MFM, Dowich V, Soares MA, Gonçalvez VC, et al. Fatores de risco e prevalência da infecção pelo HPV em pacientes de Unidades Básicas de Saúde e de um Hospital Universitário do Sul do Brasil. Rev Bras Ginecol Obstet. 2013; 35(5):226-32.

15. Matos SDO, Oliveira TMF, Andrade SSC, Oliveira SHS. Oliveira TMF, Andrade SSC. Risk behavior and self-perceived vulnerability to stis and aids among women. Rev Enferm UFPE online [Internet]. 2016 [cited 2017 Mai 04]; 10(1):13742. Available from:http://www.revista.ufpe.br/ revistaenfermagem/index.php/revista/article/ view/8610/pdf_9360

16. Martins KP, Costa KNFM, Rezende LCM, Gomes TM, Dantas TRA, Santos SR. Percepção da equipe de enfermagem acerca da acessibilidade física e de comunicação de pessoas com deficiência visual. Cienc Cuid Saúde. 2015; 14(2):1019-26. 